many titles one expects to find are missing. One medium-sized university library checked subscribes to almost two hundred periodicals in the field of biology (excluding medicine). This is not an outstanding collection, by any means, but it is a very respectable one and includes most of the important titles in the field. Of these titles, over thirty do not appear in Ulrich's, including such important journals as Annales botanici, Archives de zoologie experimentale et génerale, Cellule, and Zeitschrift für Biologie. Proportions of other fields checked were better, but such standard titles as the Classical Weekly, Journal of Bible and Religion, and Music Library Association Notes ought not to be omitted when seemingly every periodical relating to flying saucers, including such an improbable title as Thy Kingdom Come, is carefully listed. The problem of selection is undoubtedly the toughest faced by an editor of such a reference work. The only logical attempt at a solution is to concentrate on thoroughness of coverage in the type of material for which the volume will be most consulted (and this comment is only from the point of view of the university librarian) and to include others only in so far as time and expense permit.

This raises another question. It is difficult to draw a strict line of definition between periodicals and other serials. But it must be drawn this side of the Union List of $\mathrm{Se}$ rials, Literary Market Place, and Deutsche Presse. It should, in my opinion, also be drawn this side of monographic series and academy transactions, unless they appear fairly frequently and with some regularity as do not, for example, the Memoirs of the American Mathematical Society or the Smithsonian Miscellaneous Collections. With the constantly increasing number of national and subject bibliographies, information on monographic series is relatively easy to find. Because of this, it is unfortunate that so many periodicals are omitted and so many other titles not primarily within the scope of the book are included.

There are some changes in form that may be suggested. "Price not given" appears too frequently. If the periodical can be obtained free, this should be stated, even if it must appear (as it does under a number of entries) as an uncertain "Free?" If the price varies, the approximate annual cost might be estimated. To be sure, this is often a ticklish proposition, but Ulrich's is consulted for prices as much as any other information. (Incidentally, prices should be added to the information given in one of the very useful new features, the list of newspapers.) Another helpful addition would be to give for each periodical the most recent volume number and date. Finally, I would like to see entries consistent with LC in form and capitalization.

After all critcism, I can only say that the usefulness of Ulrich's is beyond question. This is not intended as a mere palliative, and if $I$ have not made a point in repeating its virtues, it is only because we have all been so dependent on it that we are familiar with them, and grateful for them. I hope, however, that some of the limitations pointed out will help in its use, and possibly serve its compilers to make future editions even more valuable.-Evan I. Farber, Emory University Library.

\section{Soviet Libraries}

Libraries and Bibliographic Centers in the Soviet Union. By Paul L. Horecky. (Indiana University Publications. Graduate School. Slavic and East European Series, v. 16.) [Bloomington, Indiana] Indiana University Publications [1959]. 287p.

Mr. Horecky's book is timely. The increased interest in Soviet contributions to science, and the growth in the purchases of Russian books and the exchange activities between American and Russian libraries have created a desire for a thorough knowledge of the Soviet library system and the demand for a publication presenting a detailed and systematic description of Soviet libraries and bibliographic centers. The articles on various aspects of Soviet libraries which have appeared in American library periodicals and the UNESCO Bulletin for Libraries from time to time, although shedding much light on the topic under review, could not entirely satisfy the demand for an organized picture of the entire library system. 
The book consists of two parts: Part I, more than 160 pages, is an outline of library organization and library activities in the Soviet Union. Part II, (pp. 163-287) consists of thirty-five translations of primary sources pertaining to Soviet libraries-such as excerpts from organizational manuals, statistical tables, classification tables, materials on training in librarianship, activities of the All-Union Book Chamber, and the wages of librarians. These translations, in addition to serving as elaborations of certain problems sketched in the book, will be useful to anyone approaching primary sources pertaining to Soviet libraries.

Part I of the book covers a broad field. It includes a description of mass libraries, with special chapters devoted to the Lenin State Library of the USSR in Moscow, the Saltykov-Shchedrin State Public Library in Leningrad, trade-union libraries, libraries in collective farms, and special libraries such as those of science and technology, educational establishments (including elementary, secondary, and higher education), the network of the USSR Academy of Sciences, the Republic Academies of Sciences, the humanities, and social sciences. It also describes buildings, the storage of library materials, and such mechanics as: purchasing, cataloging and classification, international exchange, loan services, selection of books, weeding of obsolete materials, and training of librarians.

The book gives sufficient general information of the Soviet library system; that is, of the existence of a few library networks centrally controlled, providing materials for defined groups of readers, as well as the distinctive characteristics of the system, namely: (1) a legal deposit copy system which provides a means of enriching the collections of libraries entitled to copies from this deposit and enables the All-Union Book Chamber to compile the complete bibliog. raphy of Soviet book production; (2) the preference for a classified catalog, and the recent development of various types of union catalog: retrospective and current, in Russian and other languages, All-Union and regional; (3) central cataloging and classification; (4) the weeding of collections of books which are "obsolete" from the political point of view; (5) the insignificant progress in li- brary architecture and the limited introduction of labor saving devices; and (6) the not yet satisfactorily solved problem of subject classification.

It is to Mr. Horecky's credit that he, mainly although not exclusively on the basis of Russian materials, opens vistas on the system of Soviet libraries and their workings. In presenting each of the problems, the author has supplied the date of its origin and sometimes later dates indicative of major changes in the system, and then has described its structure and methods of operation. Emphasis is on the descriptive presentation, as the author has stated in his preface. Analysis is not carried far beyond the descriptive level. The presentation is a picture seen mostly through official data and. to a lesser extent, through the eyes of observers. The clarity of presentation merits commendation and is aided extensively by schematic diagrams.

The handiness and usefulness of the publication has been enhanced by the Index, the Glossary, and the "Selective Bibliography of Sources in English and Russian," which supplements the sources cited in the text.

The book will serve admirably the librarian who is interested in the development of Russian libraries, the reference librarian in a Slavic division, and to an even greater extent, the practically oriented librarian who is engaged in the purchasing from and exchange of books with the Soviet Union.

The reviewer ventures a comment in the form of a postscript; namely, in addition to considering the organization and officially formulated goals of the libraries, an attempt might be made to pursue the investigation further, in order to determine the degree of correlation between declared goals and actual achievements, as well as to show the social factors operating in libraries. In other words, to write an inside story of Soviet libraries. Such an investigation may reveal a different picture of Soviet libraries; for example, that a general statement pertaining to political indoctrination by libraries, which we take for granted, should be qualified as to types of library, or that MarxismLeninism, despite the pronouncements, does not play a decisive role in the Soviet preference for the classified catalog.-Jan Wepsiec, Library of Congress. 